\section{Fires: fund research for citizen safety}

This year has been marked by the tragic events of the Grenfell Tower fire in London and by huge forest fires in California, Portugal and Spain. As fire scientists and engineers, we call for substantially more funding for fire research, which is currently negligible worldwide.

Even though fire has been a risk to humanity for millennia, our understanding of how it spreads is limited to semi-empirical correlations. There are many unknowns that threaten global public safety and incur billions of dollars of expenditure annually to protect property, communities, businesses and the environment.

Following our open letter to the European Commission on 23 June (go.nature.com/2hjaazy), there has been intense discussion of fire-safety issues in the media. However, most of the crucial questions cannot yet be answered. As well as a fundamental theory to explain fire spread (M. A. Finney et al. Proc. Natl Acad. Sci. USA 112, 9833-9838; 2015), we need to determine how fire and climate affect each other, how humans behave in an emergency (M. Moussaïd et al. J. R. Soc. Interface 13, 20160414 ; 2016) and how best to respond to fires to minimize their consequences (N. Pidgeon and M. O'Leary Safety Sci. 34, 15-30; 2000). Only then can we develop and implement proper safety technologies.

Georgios Boustras European University Cyprus, Egkomi, Cyprus. Enrico Ronchi Lund University, Sweden.

Guillermo Rein Imperial College London, UK.

g.boustras@euc.ac.cy

\section{Fires: degree courses for fire professionals}

Catastrophic forest fires have ravaged parts of Chile, California, Portugal and Spain this year. To meet the challenge of managing wildfires as essential ecosystem components while avoiding their negative societal impacts, we suggest that the current political and scientific agenda should include new science-based education programmes for fire professionals.

Wildfire activity has risen in recent years. The conventional response has been to increase resources for fire extinction, but the few blazes that escape can quickly become mega-fires. More fire analysts are needed worldwide who can take realtime decisions to effectively manage such breakaway wildfires according to each particular set of circumstances.

Using science to inform education would better equip fire professionals to tackle such catastrophes as they become more frequent. Carefully designed degree programmes would bring together disparate research on applied fire science and provide instruction on wildfire management and on forest ecology and evolution. Such courses could also improve understanding of the effects of global change on wildfires and of emergency strategies and responses.

Víctor Resco de Dios, Domingo Molina-Terrén University of Lleida, Spain. vic@pvcf.udl.cat

\section{Empower Africa's electricity sector}

In a US House of Representatives hearing last month, the administration of President Donald Trump revealed that it would cut funds for the Power Africa initiative. The cuts are likely to have a significant impact because Power Africa affects how the continent's power sector operates.

Power Africa was set up by former president Barack Obama to help bring electricity to subSaharan Africa, a region where two-thirds of the population has no access. Since its launch in
2013, most of the sector's funding, policy design and, crucially, necessary knowledge and skills have come from outside of Africa.

Yet US financial contributions to Power Africa come at a price: power-infrastructure contracts are awarded mainly to US energy companies. Furthermore, African governments are asked to reduce import taxes and implement cost-reflective electricity prices, easing access by foreign firms to the market. Such measures make it difficult to protect domestic African energy industries, and jeopardize schemes that help poor people to pay for electricity.

Africa's increasing demand for electricity, coupled with its prolific resources for renewable energy, present an opportunity to develop a strong African-run power industry. International assistance should be used to make this domestic industry sustainable and more competitive, without leaving it vulnerable to political change abroad.

Philipp Trotter University of Bath, UK.

Sabah Abdullah University of Queensland, Brisbane, Australia. p.trotter@bath.ac.uk

\section{Meet patients to sharpen up research}

Shoddy preclinical research is not just bad science - it is unethical. It stalls cures and exposes people to drug trials that cannot work (see, for example, G. Cossu et al. The Lancet http:// doi.org/cf29; 2017). Researchers need a better appreciation of the connection between sloppy results and the consequences to people who have a disease.

Much ink has been spilled about poor study design, lack of appropriate controls, nonblinded investigators and low statistical power. Yet the research community is failing to correct such flaws, as attested by the latest report on the ARRIVE guidelines, which were issued in 2010 to improve animal studies and are now endorsed by more than 1,000 journals (M. Enserink Science 357, 1337-1338; 2017).

In our view, a firm connection between researchers and the reality of the diseases they study would help. It is all too common for a preclinical researcher never to have met a person with the disease they are working on. They therefore do not fully appreciate patients' hopes and aspirations or the burden of the illness.

Preclinical researchers need to disavow the idea that sponsors or regulators will protect patients from work of low quality. The many premature and unwarranted clinical trials prove that they don't. One example is a neural stem-cell product that was tested in a clinical trial despite negative preclinical findings (A. J. Anderson et al. Stem Cell Rep. 8, 249-263; 2017).

Mark Yarborough University of California, Davis, USA. Ulrich Dirnagl Charité University Medicine Berlin, Germany. mayarborough@ucdavis.edu

\section{An open market for scientific verbiage?}

It strikes me that Brian Martinson's suggestion to put a lifetime cap on the number of words published by scientists could be enhanced by the addition of a 'trade' option, as with carbon-offset credits (see Nature 550, 303; 2017). That way, those scientists who are economical with their publication count and strategic with their word choices could sell their excess word allocation to the highest bidder.

One wonders how much could be collected through an open market in scientific verbiage for expressions such as 'it is easily shown that' or 'we applied the standard statistical analyses to the data' or 'we conclude that more observations are required'.

Kevin B. Marvel American Astronomical Society, Washington DC, USA. kevin.marvel@aas.org 